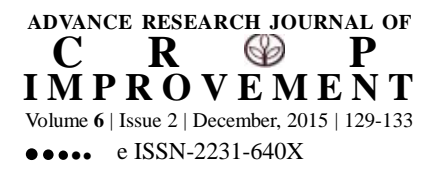

DOI :

10.15740/HAS/ARJCI/6.2/129-133

Visit us: www.researchjournal.co.in

\section{Growth and yield attributes as influenced by integrated weed management in soybean [Glycine max (L.) Merrill]}

\author{
R.R. JAKHAR AND R. SHARMA
}

\begin{abstract}
A field experiment was conducted in alluvial loamy soil at Experimental Farm of Division of Agronomy, IARI, New Delhi during Kharif season of 2010. The experiment was laid out in Randomized Block Design and replicated thrice. The experiment consisted of twelve treatments of weed control measures $\left(\mathrm{T}_{1}\right.$ - pendimethalin @ $1000 \mathrm{~g} / \mathrm{ha} \mathrm{PE} ; \mathrm{T}_{2}$ - pendimethalin @ $750 \mathrm{~g} / \mathrm{ha}$ PE +1 cono weeding at $30 \mathrm{DAS} ; \mathrm{T}_{3}$ - diclosulam @ $18 \mathrm{~g} / \mathrm{ha} \mathrm{PE} ; \mathrm{T}_{4}$-diclosulam @ $16 \mathrm{~g} /$ ha PE +1 cono weeding at $30 \mathrm{DAS} ; \mathrm{T}_{5}$ - diclosulam @ $22 \mathrm{~g} / \mathrm{ha}$ PE; $\mathrm{T}_{6}$ - diclosulam @ $20 \mathrm{~g} / \mathrm{ha} \mathrm{PE}$ +1 cono weeding at $30 \mathrm{DAS} ; \mathrm{T}_{7}$ - diclosulam @ $26 \mathrm{~g} / \mathrm{ha} ; \mathrm{T}_{8}$ - diclosulam @ $24 \mathrm{~g} / \mathrm{ha} \mathrm{PE}+1$ cono weeding at $30 \mathrm{DAS} ; \mathrm{T}_{9}$ - imazethapyr @ $75 \mathrm{~g} / \mathrm{ha}$ at $20 \mathrm{DAS} ; \mathrm{T}_{10}$ - two cono weedings at 20 and 40 DAS; $T_{11}$ - weedy-check; $T_{12}$ - weed-free check). The result in treatment weed-free check significantly higher of CGR and plant population $/ \mathrm{m}^{2}$ were at harvest and remained at par with two cono weedings at 20 and 40 DAS (30-90 DAS). However, application of pendimethalin @ $1000 \mathrm{~g} / \mathrm{ha}$ PE being significantly was higher and it remained at par with application of diclosulam @ $24 \mathrm{~g} / \mathrm{ha} \mathrm{PE}+1$ cono weeding 30 DAS (60-at harvest). The application of pendimethalin @ $1000 \mathrm{~g} / \mathrm{ha}$ PE being significantly higher it remained at par with application of weedy check over the rest of treatments at 60-at harvest of RGR. The result in treatment weed-free check significantly higher harvest and remained at par with diclosulam @ $20 \mathrm{~g} / \mathrm{ha} \mathrm{PE}+1$ cono weeding at 30 DAS and two cono weedings at 20 and 40 DAS (30-90 DAS) over other treatments. The application of pendimethalin @ $1000 \mathrm{~g} / \mathrm{ha}$ PE in case of HI and remained at par with the application diclosulam @ $18 \mathrm{~g} / \mathrm{ha}$ PE, diclosulam @ $22 \mathrm{~g} / \mathrm{ha}$ PE, diclosulam @ $24 \mathrm{~g} / \mathrm{ha} \mathrm{PE}+1$ cono weeding at 30 DAS, imazethapyr @ $75 \mathrm{~g} / \mathrm{ha} 20$ DAS and weedy-check over rest of treatments. The treatment weed-free check was significantly higher in case of 1000-seed weight over the rest of treatments. They did not significantly affect the integrated weed management on RGR (30-60 DAS) and seed per pods. Season long weed free condition brought the higher increase in the yield attributes, seed yield and stover yield of soybean which was statistically similar with two cono weedings at 20 and 40 DAS and pre-emergence application of diclosulam @ $20 \mathrm{~g} / \mathrm{ha}+1$ cono weeding at 30 DAS. Season long weed free situation recorded 76.96 per cent increase in grain yield as compared to season long weed competition. Herbicidal treatments provided a yield advantage of 54.44 to 74.53 per cent over weedy-check.
\end{abstract}

KEY WORDS : CGR, Diclosulam, Imazethapyr, Pendimethalin, Pre-emergence, RGR, Soybean, Yield

How to cite this paper : Jakhar, R.R. and Sharma, R. (2015). Growth and yield attributes as influenced by integrated weed management in soybean [Glycine max (L.) Merrill]. Adv. Res. J. Crop Improv., 6 (2) : 129133.
Paper History : Received : 12.06.2015; Revised : 02.10.2015; Accepted : 16.11 .2015
Author for correspondence: R.R. JAKHAR

Division of Agronomy, Indian

Agricultural Research Institute, NEW DELHI (INDIA)

Email : ruparamjakhar@gmail.com 